The Committees invite criticism and comment, which will be considered before further editions are issued. No doubt individual teachers will have constructive suggestions to make, and probably the very detailed list of topics for study and omission will be revised from time to time; but the syllabuses as a whole will be widely welcomed, representing as they do a standard which the majority of sixth-form "boys should be able to reach.

Teachers and examiners, who have for many years accepted with patience the hitherto untested hypothesis that many of the defects of their students are due to their own excessive zeal, will have another reason for welcoming the new syllabuses. One factor responsible for literary incapacity, narrowness of outlook, and other personal shortcomings, has now been much reduced in magnitude; should these failings still persist appreciably, attention may in future be turned to other factors in the curriculum. Mere absence of intensive specialization is not enough; a sound general course for the sixth-form science student calls for the best that the humaner studies can provide, and they now have their chance.

The shifting of emphasis from the needs of the gifted few to the needs of the majority still leaves a problem to be faced. The good scholarship boy at present enters the sixth form at the age of fifteen, takes a higher school certificate examination for the first time at sixteen or seventeen, and then (in peace-time) has a year and a term at least in which to compete for awards, proceeding to the university at eighteen or nineteen. With the proposed scheme, it seems likely that boys of scholarship calibre may gain awards at seventeen, which is generally considered too young for entering a university. It would appear undesirable for these boys to spend a further year at school simply marking time with the rest of the class, and anticipation of university work is one of the disadvantages of the present system. It would be valuable indeed if the Committees, in later issues of the syllabuses, could round off an already excellent job by suggesting general syllabuses covering a year's post-higher school certificate work for those who are preparing either to enter a university or start directly on their careers after a final year at school.

\section{AGRICULTURAL EDUCATION ASSOCIATION}

\section{JUBILEE MEETING}

$\mathrm{T}$ HE Agricultural Education Association celebrated its fiftieth birthday at a luncheon at the Holborn Restaurant, which took place during the annual conference held during December 12 and 13 in London. The principal guest was the Minister of Agriculture, who had with him Sir George Courthorpe, president of the Royal Agricultural Society, Mr. Nevill, representing the National Farmers' Union, the United States agricultural attaché, and the. chairman of the Horticultural Education Association.

In his address, Mr. Hudson said that the Agricultural Education Association has important functions to perform; not the least is the opportunity. it affords workers of meeting and getting to know each other. He referred to the legislation which has recently been passed providing for the establishment of a unified National Agricultural Advisory Service, and defended the decision to separate responsibility for farm institutes from the main scheme. "We want and intend to make this Service one which by its conditions, its opportunities of advancement and its scope will attract to it the most highly qualified men in all its branches", the Minister continued.

Mr. Hudson stressed the importance which he attaches to the twin jobs of edueation and advice for the future of agriculture. The future of the industry will depend upon the ability of the farmer to produce food at prices which will bear a reasonable comparison with the prices at which we can buy food from. overseas; to do this, the industry must make use of all the latest scientific discoveries, all the most up-to-date methods that exist in the world and are suitable for British conditions. The farmer is not a person who is able to travel about freely and see and learn things for himself; it must be through the eyes and ears of technical advisers that he will be able to keep abreast of modern developments. Mr. Hudson said he is anxious about the great scarcity which exists to-day of good technical men. Men must be found for the Advisory Service; men to teach the older students at the universities and colleges; men to teach the younger students at the farm institutes; men to instruct the large numbers of ex-Servicemen; men to staff the research stations, and so on. Men with an expert agricultural training will also be wanted by commercial firms, by the Colonial Agricultural Service and in other fields. Therefore it might be difficult for a time to push on as rapidly as he would like.

Dr. Charles Crowther had previously given an account of the early days of the Association. It was founded in 1894 at the instance of Mr. Brooke-Hunt, then the one education inspector of the Board of Agriculture. At first the membership was small, consisting of a handful of heads of agricultural educational institutions and departments. Soon, membership was thrown open to members of staffs, and in 1912 the Association numbered 130. After the War of 1914-18, a great expansion took place, and the present membership is between four and five hundred. After referring to the contributions which the Association has made to experimental work, Dr. Crowther said that it has never failed to formulate its views and present them to every commission or Government committee that has reviewed the field of agricultural education during the past fifty years, and the recommendations and subsequent administrative action have shown clearly the potency of the Association's intervention. Dr. Crowther concluded with the comment that the more highly specialized agricultural education becomes the greater will be the need for the Agricultural Education Association.

A feature of the programme at this jubilee meeting were the surveys of progress during the past halfcentury in grassland, livestock and dairying. Very aptly, Sir George Stapledon contributed the review of grassland work. He claimed that permanent grass dominated the outlook at first. Even the pioneer investigations of Somerville, Gilchrist and Elliot were mainly directed towards permanent turf. To Gilchrist, Sir George gave the credit for bringing together the important factors of phosphates, wild white clover, sensible seeds mixtures and the greater needs of the farmer. He paid tribute to the valuable work on the nutritive value of grass carried out by Prof. T. W. Fagan and Dr. H. E. Woodman, saying that if we do not have a clear understanding of the factors influencing the nutritive value of grass we 
can have no scientific basis for the proper management of grassland as feed for animals. He praised very highly the pioneer work of Hosier with his milking bails, and went on to say that a two-compartment system of agriculture, based on huge areas in permanent grass and rough grazings, and lesser areas in arable land, affords the minimum of insurance against weathering catastrophe, and makes impossible a virile and adventuring agriculture throughout the country.

Mr. James Mackintosh said that the chief change in dairying has been the increase in the demand for milk for liquid consumption. In 1875, Morton estimated that only one third of the milk produced in England and Wales was used for liquid consumption. Rew, in 1892 , raised the proportion to two thirds. In 1938, of the total milk production, some 68 per cent was consumed as liquid milk, and in 1943 no less than 90 per cent was directed to the liquid milk market, and only 10 per cent was made into produce. Mr. Hudson has now said that another 350 million gallons a year will be needed before rationing of milk can be discontinued. Mr. Mackintosh discussed in turn such influences on milk production as the introduction of imported foods, of improved methods of feeding, of modern methods of housing milking cows, of milk recording, and of regulations made by Government and other bodies. This was a comprehensive and very much appreciated review of progress and development.

Prof. R. G. White, dealing with British livestock during the last fifty years, believes that the most obvious advance has been in the control of disease, particularly with regard to sheep. He referred to the influence exerted by the importation of cheap phosphatic fertilizers for grassland, and of cheap feeding stuffs, on livestock, and also on the effect of changed standards of living. $\mathrm{He}$ commented on the fact that although Great Britain is a relatively small country, there are a large number of local breeds of sheep and cattle; while he does not see any great need for starting new breeds, he would be sorry if any of the old local breeds disappeared before we obtained much fuller information than we have at present about them and their suitability for their special environments and functions. $\mathrm{He}$, too, spoke of the striking development of milk production, saying that fifty years ago about 20 per cent of our cattle were of the purely beef type, and less than 10 per cent of the purely dairy type. Now, he estimates, the figures are 25 per cent purely dairy and 15 per cent purely beef. On the subject of breeding, Prof. White said that as regards the immediate major problems of breeding policy we can still do nothing better than follow on the lines of Bakewell, nearly two hundred years ago-ruthless selection, inbreeding, followed by more ruthless selection and progeny testing. We have, however, a great advantage over Bakewell in that we understand to a great extent the effect of inbreeding. We know its value, and we realize the dangers and obstacles which are to be avoided.

A paper by Mr. E. L. Crossley described the way in which spray-dried milk powder, the demand for which in war-time has enormously increased, has been packed so as to stand up to tropical conditions for a much longer period. Specially made tins are exhausted of air after being filled with milk powder, and then supplied with nitrogen gas at a pressure of $2 \mathrm{lb}$. per sq. in. The process is simple in theory, but in practice many difficulties have to be overcome, for the vacuum employed is a low one, and the nitrogen itself must be of at least $99 \cdot 7$ per cent purity. This gas-packing process has extended the keeping quality of full-cream spray-dried milk to seven years in temperate climates and to at least three years in the tropics.

Mr. V. C. Fishwick submitted data from experiments with pigs to show that nutrition during the early life of the piglet has a considerable influence upon the breeding capacity and milk production of the gilt. If she is badly fed during the first twelve weeks of her life, she is liable to develop a short frame and a heavy fore end, and her capacity to produce pigs and milk is liable to be reduced. These conclusions can probably be applied to other farm stock; he suggested that the high price of milk encourages calf rearers to use little milk and unsuitable calf-rearing substitutes, so that the calves are raised on too low a plane of nutrition, with detrimental results on the animal's capacity to produce milk.

An unusual case of crop failure due to the presence of excess amounts of zinc in the soil was described by Mr. F. Knowles. A field in Essex had apparently been used as a dump for the disposal of dross from a munitions factory operating during the War of 191418, and when ploughed up for cropping during the present War, cereals and other crops would not grow. The trouble was traced to large amounts of zine and copper in the soil, and experiments made in pots and in the field showed that the trouble could be overcome by liming the ground. Prof. T. Wallace contributed a paper summarizing our present knowledge of mineral deficiencies in soils and crops.

Other papers were read by Mr. F. H. Garner and Dr. Dillon Weston on the growing of field beans and on the fungus diseases to which the crop is subject. There wàs also a useful discussion in the Biology Section on modern methods of pasture evaluation, the principal speakers being Mr. William Davies and Mr. J. Lambert, of the Grassland Improvement Station, Stratford-on-Avon. A small committee was set up to go thoroughly into the question of technique.

\section{THE BRITISH COUNCIL ANNUAL REPORT}

$\mathrm{T}$ HE annual report of the British Council for the year ended March 31,1944 , covers the tenth year of the Council's work and indicates not only the part the Council has played in the war effort but also its value as an instrument for the no less difficult days of peace to come. Cultural relations are not competitive but reciprocal, and no Government can look with equanimity on the prospect after the War of international competition in this field.

The British Council, with the President of the Board of Trade, initiated a Conference of Allied Ministers of Education in London, and with the Board has borne the burden of its administration, and will continue to do so until it can hand over such responsibilities to a United Nations organization. Plans for providing schools and universities with the necessary books, stationery, laboratory apparatus, radio sets and film projectors were among the subjects discussed by the Conference. Four lines of development are picked out for special mention in the report: the start of effective work in China, the increasing importance of medicine, the growing interest in British music and the services rendered to the Armed Forces 